\title{
Porphyromonas gulae sp. nov., an anaerobic, Gram-negative coccobacillus from the gingival sulcus of various animal hosts
}

\author{
1 GREB, Faculté de Médecine \\ Dentaire, Université Laval, \\ Cité Universitaire, Québec, \\ Canada G1V 7P4 \\ 2 Centre de Recherche en \\ Infectiologie de \\ I'Université Laval, CHUQ \\ pavillon CHUL, 2705 Boul. \\ Laurier, Sainte-Foy, \\ Québec, Canada G1V 4G2 \\ 3 Oral Health Science Center, \\ Tokyo Dental College, \\ Department of \\ Microbiology, 1-2-2 \\ Masago, Mihama-ku, \\ Chiba 261-8502, Japan
}

\author{
Dominique Fournier, ${ }^{1} \dagger$ Christian Mouton, ${ }^{1} \ddagger$ Pascal Lapierre, ${ }^{2}$ \\ Tetsuo Kato, ${ }^{3}$ Katsuji Okuda ${ }^{3}$ and Christian Ménard ${ }^{2}$
}

Author for correspondence: Christian Ménard. Tel: +1 418654 2705. Fax: +1 4186542715. e-mail: christian.menard@crchul.ulaval.ca
Keywords: Porphyromonas gulae sp. nov., Porphyromonas gingivalis, DNA-DNA hybridization, 16S rRNA sequencing, Old World monkey

\section{INTRODUCTION}

The taxonomy of the genus Porphyromonas has evolved quite rapidly in recent years (Jousimies-Somer, 1995, 1997). It was originally proposed (Shah \& Collins, 1988) to accommodate three species found in humans, Porphyromonas gingivalis, Porphyromonas asaccharolytica and Porphyromonas endodontalis, all

\footnotetext{
† Present address: Service Canadien des Forêts, Centre de foresterie des Laurentides, 1055 rue du P.E.P.S., C.P. 3800, Sainte-Foy, Québec, Canada G1V 4C7.

¥Present address: Le Grand Jaure, 31 voie romaine, 24100 Lambras, France.

Abbreviations: $\quad \beta$-GAL, $\beta$-galactosidase; $\quad \beta$-NAG, $\quad N$-acetyl- $\beta$-Dglucosaminidase; PA, phenylacetic acid; RAPD, randomly amplified polymorphic DNA; UPGMA, unweighted pair group method with arithmetic averages.

The GenBank accession numbers for the 16S rRNA gene sequences of $P$. gulae sp. nov. isolates Loup $1^{\top}$ (ATCC $51700^{\top}$ ), Chat 3.1, Ours 3.1, B 243, Chien 4.2 and Coyote 1.5.1 are AF208290, AF285871, AF285872, AF285874, AF285873 and AF287986, respectively.
}

of which are strictly anaerobic, Gram-negative, nonspore-forming and non-motile rod-shaped chemoorganotrophs. Colonies develop a brown to black pigment on laked blood agar plates within the first $48 \mathrm{~h}$ of growth. Subsequent studies on samples obtained from dogs led to the description of several new species: Porphyromonas cangingivalis and Porphyromonas cansulci (Collins et al., 1994), Porphyromonas gingivicanis and Porphyromonas crevioricanis (Hirasawa \& Takada, 1994), and Porphyromonas canoris (Love et al., 1994). It is noteworthy that these species have all been associated with development of periodontitis in the animal. Based on 16S rRNA phylogenetic analyses, Oribaculum catoniae (Moore \& Moore, 1994) was reassigned to the Porphyromonas genus (Willems \& Collins, 1995). In addition, some isolates obtained from various animals have closely resembled $P$. gingivalis strains of human origin, but differed in terms of catalase activity (Laliberté \& Mayrand, 1983) and antigen specificity (Parent et al., 1986), suggesting the existence of two biotypes within the species $P$. gingivalis. 
Studies based on phenotypic characteristics (Fournier $\&$ Mouton, 1993), DNA-DNA reassociation (Kato et al., 1997), multilocus enzyme electrophoresis (MLEE) (Loos et al., 1993) and randomly amplified polymorphic DNA (RAPD) typing (Ménard \& Mouton, 1993) have confirmed the existence of two biotypes within the $P$. gingivalis taxon, one of human origin and the other of animal origin. In particular, two DNAbased studies (Kato et al., 1997; Ménard \& Mouton, 1995) and an MLEE study (Loos et al., 1993) have demonstrated sufficient genetic distance between isolates of both origins to warrant their assignation to separate species. This led us to believe that strains recovered from the gingival plaque of animals represented a cryptic species within the $P$. gingivalis taxon.

The new data we report here have been added to those previously published, and involve morphological, biochemical, physiological and genetic analyses conducted on strains representing the two biotypes and genetic clusters previously outlined. This information has led to the proposal of a new species, Porphyromonas gulae sp. nov.

\section{METHODS}

Bacterial strains. This investigation required a collection of strains to represent accurately the animal as a host. A total of 67 isolates of black-pigmented, Gram-negative, anaerobic coccobacilli to rod-shaped bacteria identified as $P$. gingivalis animal biotype was included in this study. This collection reflected a wide geographical and host diversity (Table 1). The isolates came from Canada, the United States, Australia and Japan. The animal reservoir included bear, cat, coyote, dog, wolf and monkey. Most strains were freshly isolated and some were originally identified by the donor laboratory and subsequently screened with our typing scheme. A collection of $P$. gingivalis human biotype and reference strains from other Porphyromonas species was also included (Table 1). In addition, the published characteristics for type strains of newly named species, particularly from dogs, that had not been described at the time of our experimentation have been taken into account. Those strains used for further comparison are: $P$. canoris NCTC $12835^{\mathrm{T}}$, P. gingivicanis ATCC $55562^{\mathrm{T}}, P$. crevioricanis ATCC $55563^{\mathrm{T}}, P$. cangingivalis NCTC $12856^{\mathrm{T}}$ and $P$. cansulci NCTC $12858^{\mathrm{T}}$. Finally, because they are close relatives of the species under study, the cat isolate Porphyromonas circumdentaria VPB 3325, and a frequent colonizer of the oral cavity in children, Porphyromonas catoniae ATCC $51270^{\mathrm{T}}$ (Willems \& Collins, 1995), first described as Oribaculum catoniae (Moore \& Moore, 1994), were included in our comparison.

Growth conditions. Bacteria were usually grown to midexponential phase in Todd-Hewitt broth (BBL Microbiology Systems) enriched with haemin $\left(10 \mu \mathrm{g} \mathrm{ml}^{-1}\right.$; SigmaAldrich) and vitamin $\mathrm{K}_{1}\left(1 \mathrm{mg} \mathrm{ml}^{-1}\right.$; Sigma-Aldrich). Trypticase Soy broth (BBL Microbiology Systems), enriched as above, was used specifically to grow cultures for DNA homology analysis. Otherwise, cultures were maintained on plates using the Todd-Hewitt base with $1.5 \%(\mathrm{w} / \mathrm{v})$ agar (Difco) and 2\% (v/v) laked human erythrocytes (Red Cross). All cultures were incubated in an anaerobic chamber (Coy Manufacturing) in a gas atmosphere composed of $80 \%(\mathrm{v} / \mathrm{v}) \mathrm{N}_{2}, 10 \%(\mathrm{v} / \mathrm{v}) \mathrm{CO}_{2}$ and $10 \%(\mathrm{v} / \mathrm{v}) \mathrm{H}_{2}$ at a constant temperature of $37^{\circ} \mathrm{C}$.
Isolation and biochemical identification. The protocols used for isolation and identification of anaerobic microorganisms from the oral microflora of various animal hosts have been described previously (Fournier \& Mouton, 1993). Our complete phenotyping scheme, run in duplicate, included colony fluorescence, catalase, trypsin-like and haemagglutinating activities, biochemical tests from the RAPID ID 32A (formerly ATB 32A) kit (bioMérieux) and GLC analysis of metabolic end products. GLC analysis was carried out using a gas-liquid chromatograph (model 5830A; Hewlett Packard) equipped with a hydrogen flameionization detector as outlined in the Virginia Polytechnic Institute Manual (Holdeman et al., 1977). Peaks were recorded and integrated with a Hewlett Packard GC terminal, model 18850A (chart speed $1.0 \mathrm{~cm} \mathrm{~min}^{-1}$ ). The carrier gas was helium $\left(80 \mathrm{ml} \mathrm{min}^{-1}\right)$ and the injection port temperature was $120^{\circ} \mathrm{C}$ (for volatile fatty acids) or $125^{\circ} \mathrm{C}$ (for non-volatile fatty acids). Ten-microlitre aliquots of ether-extracted or methylated and chloroform-extracted samples from Todd-Hewitt broth supernatants were injected into a coiled glass column packed with 10\% Fluorad FC 431 (Chromatographic Specialties) plus $1 \% \mathrm{H}_{3} \mathrm{PO}_{4}$ on acidwashed Chromosorb W (80-100 mesh; Johns-Manville) (for volatile fatty acids) or with $10 \%(\mathrm{w} / \mathrm{w})$ Resoflex LAC1-R296 (Chromatographic Specialties) on acid-washed Chromosorb AW (45-50 mesh; Johns-Manville) (for nonvolatile fatty acids). The results were compared with those obtained using standard $10 \mathrm{mM}$ solutions of acetate, propionate, isobutyrate, butyrate, isovalerate, valerate, lactate, succinate and phenylacetate (Sigma-Aldrich).

An additional method, using 4-methylumbelliferone derivatives (Moncla et al., 1991), was used for the detection of $\alpha$ galactosidase, $\beta$-galactosidase, $\alpha$-glucosidase, $\beta$-glucosidase, $\alpha$-fucosidase and neuraminidase (sialidase) activities and $N$-carbobenzoxy-L-arginine-7-amido-4-methylcoumarin for trypsin-like activity. Briefly, Whatman no. 2 strips $(\sim 6 \times 60 \mathrm{~mm})$ were soaked with substrate solutions; a loopful of bacterial growth was then smeared on each strip and the strips incubated for $15 \mathrm{~min}$ at $37{ }^{\circ} \mathrm{C}$ in the dark. The paper strips were then examined under a long-wavelength (366 nm) hand-held UV lamp (UltraViolet Products). The enzymic activity was visualized by the appearance of a fluorescent blue spot around the smear on the filter paper strip.

RAPD fingerprinting (Ménard \& Mouton, 1995). We examined 98 strains recovered from 79 human subjects and 32 more recovered from 30 animals of nine different species. RAPD was carried out on purified DNA using modifications (Ménard et al., 1992) of the original method (Williams et al., 1990). To assess overall genetic relatedness (genetic affinity), a data matrix scoring major amplicons as 1 (present) and 0 (absent) was first compiled for each isolate. Similarities between all tested strains were then estimated using the Nei coefficient (Nei \& Li, 1979): $F=\left(2 n_{\mathrm{xy}} / n_{\mathrm{x}}+n_{\mathrm{y}}\right)$ where $n_{\mathrm{xy}}$ is the number of bands common to strains $\mathrm{x}$ and $\mathrm{y}$, and $n_{\mathrm{x}}$ and $n_{\mathrm{y}}$ are the total number of bands in each strain. These data were clustered according to the unweighted pair group method with arithmetic averages (UPGMA) (Sneath \& Sokal, 1973) yielding a dendrogram. Data handling was performed with the R package (Legendre \& Vaudor, 1991) and we used the PHYLIP program (Felsenstein, 1993) for reconstruction.

DNA homology methods and determination of $\mathbf{G}+\mathbf{C}$ content (Kato et al., 1997). Chromosomal DNA was extracted and purified by the method of Marmur (1961). Excluding the 
Table 1. Clinical Porphyromonas strains used in this study

\begin{tabular}{|c|c|c|c|}
\hline Strain & Infection or diagnosis & $\begin{array}{l}\text { Host (no. carrier } \\
\text { animals/no. } \\
\text { sampled animals) }\end{array}$ & Geographic origin \\
\hline \multicolumn{4}{|l|}{$\begin{array}{l}P . \text { gingivalis animal biotype } \\
(P \text {. gulae } \text { sp. nov. })\end{array}$} \\
\hline \multicolumn{4}{|l|}{ Received isolates (15) } \\
\hline 3318,3492 & Healthy gingival sulcus & Cats & Dr D. N. Love, Australia \\
\hline A 1834, B 243, G 251, I 372, I 433 & Experimental periodontitis & Monkeys* & Dr W. P. McArthur, FL, USA \\
\hline Bas beagle PZ4T +, DogID12 & Healthy gingival sulcus & Dogs & Dr S. A. Syed, MI, USA \\
\hline Chat 1 , Chat 3(7) & Healthy gingival sulcus & Cats & Dr D. Mayrand, Quebec \\
\hline Chien 5B, Chien N9 & Healthy gingival sulcus & Dogs & Dr D. Mayrand, Quebec \\
\hline D2-9, D2-10 & Healthy gingival sulcus & Dogs & Dr K. Okuda, Japan \\
\hline \multicolumn{4}{|l|}{ Freshly recovered isolates (52) } \\
\hline Ours 3.1 & Healthy gingival sulcus to gingivitis & Bears $(1 / 2)$ & Own isolates, Quebec \\
\hline $\begin{array}{l}\text { Chat strains }(8): 1.3,2.4,2.5,3.1,3.31 \text {, } \\
3.3 \mathrm{~S} 1,6.21,6.32\end{array}$ & Healthy gingival sulcus to gingivitis & Cats $(6 / 6)$ & Own isolates, Quebec \\
\hline $\begin{array}{l}\text { Coyote strains }(12): 1.4 \mathrm{~S} 2,1.4 \mathrm{~S} 3,1.43 \mathrm{f} \\
1.43 \mathrm{p}, 1.5 \mathrm{~S} 1 \mathrm{f}, 1.5 \mathrm{~S} 1 \mathrm{p}, 1.5 \mathrm{~S} 2,1.5 .1,1.52 \\
1.53,1.55,1.56\end{array}$ & Gingivitis & Coyote $(1 / 1)$ & Own isolates, Quebec \\
\hline $\begin{array}{l}\text { Chien strains }(21): 4.2,5.3 \mathrm{~S} 1,5.41,5.42 \text {, } \\
5.43,6.31,6.32,6.41,6.51,7.2 \mathrm{~S} 1,7.2 \mathrm{~S} 2 \\
\text { 7.3S1, 8.31, } 8.32,8.3 \mathrm{~S} 1,9.3 \mathrm{~S} 1,9.4 \mathrm{~S} 1,9.51,10.21,10.2 \mathrm{~S} 1,10.3 \mathrm{~S} 1\end{array}$ & Gingivitis & Dogs $(3 / 3)$ & Own isolates, Quebec \\
\hline Ateles strains (5): $5.3 \mathrm{~S} 1,5.4 \mathrm{~S} 1,5.51,5.52,5.5 \mathrm{~S} 1$ & Periodontitis & Monkeys $(1 / 3) \dagger$ & Own isolates, Quebec \\
\hline $\begin{array}{l}\text { Loup strains }(5): 1\left(=\text { ATCC } 51700^{\mathrm{T}}\right), 1.2 \mathrm{~S} 1 \text {, } \\
2.2 \mathrm{~S} 1,2.3 \mathrm{~S} 1,2.4 \mathrm{~S} 1\end{array}$ & Healthy gingival sulcus to gingivitis & Wolves $(2 / 2)$ & Own isolates, Quebec \\
\hline \multicolumn{4}{|l|}{ P. gingivalis human biotype (13) } \\
\hline $\begin{array}{l}\text { ATCC } 33277^{\mathrm{T}} \text {, ATCC } 53977 \text {, ATCC } 53978, \\
\quad \text { ATCC } 49417\end{array}$ & $\begin{array}{l}\text { Healthy gingival sulcus, } \\
\text { mellitus diabetes, clinical isolate, } \\
\text { periodontal pocket }\end{array}$ & Human & ATCC, VA, USA \\
\hline 381 & Periodontal pocket & Human & Dr S. S. Socransky, MA, USA \\
\hline OMG 406 & Unknown & Human & Dr G. Dahlén, Kenya \\
\hline $16-1$ & Juvenile periodontitis & Human & Dr K. Okuda, Japan \\
\hline HW24D-5 & Periodontal pocket & Human & Dr D. Mayrand, Quebec \\
\hline $\mathrm{I}-2$ & Unknown & Human & Dr K. Okuda, Japan \\
\hline R113 & Periodontal pocket & Human & Dr J.-C. Robert, France \\
\hline JKG-1 & Buccal cavity & Human & Dr S. A. Syed, MI, USA \\
\hline Cerco 1.5.2 & Gingivitis & Monkeysł! & Own isolates, Quebec \\
\hline Manga 1.41 & Gingivitis & Monkeys§ & Own isolates, Quebec \\
\hline \multicolumn{4}{|l|}{ P. endodontalis (1) } \\
\hline ATCC $35406^{\mathrm{T}}$ & Infected root canal & Human & ATCC, VA, USA \\
\hline \multicolumn{4}{|l|}{ P. asaccharolytica (2) } \\
\hline ATCC $25260^{\mathrm{T}}$, ATCC 27067 & Empyema, leg wound & Human & ATCC, VA, USA \\
\hline \multicolumn{4}{|l|}{ P. circumdentaria (1) } \\
\hline VPB 3325 & Normal margin & Cat & Dr D. N. Love, Australia \\
\hline \multicolumn{4}{|l|}{ P. macacae (2) } \\
\hline ATCC $33141^{\mathrm{T}}$, ATCC 49407 & Periodontal pocket, normal margin & Monkey\|, cat & $\begin{array}{l}\text { ATCC, VA, USA, } \\
\text { Dr D. N. Love, Australia }\end{array}$ \\
\hline \multicolumn{4}{|l|}{ P. levii (1) } \\
\hline ATCC $29147^{\mathrm{T}}$ & Rumen & Cow & ATCC, VA, USA \\
\hline
\end{tabular}

* Isolated from Saimiri scuireus (common squirrel monkey).

$\dagger$ Isolated from Ateles paniscus (black spider monkey).

\$ Isolated from Cercocebus torquatus lunulatus (white-collared mangabey).

$\S$ Isolated from Cercopithecus nictitans (greater white-nosed monkey).

|| Isolated from Macaca arctoides (stumptailed macaque).

coyote, a representative strain was selected for each host for this part of the study. DNA purity was assessed by the $A_{260} / A_{280}$ ratio and by agarose gel electrophoresis. To prepare labelled DNA in vitro, the nick translation system [3H]- (Du Pont NEN Products), which is an adaptation of the procedure described by Rigby et al. (1977), was used.

DNA similarity values were determined by means of the S1 nuclease procedure as described previously (Kato et al., 1987). A reaction mixture containing 0.01 $\mu \mathrm{g}$ labelled DNA and $10 \mu \mathrm{g}$ unlabelled DNA was incubated for $24 \mathrm{~h}$ at $65^{\circ} \mathrm{C}$. $\mathrm{S} 1$ nuclease digestions were carried out using $0.5 \mathrm{U}$ of the enzyme (Seikagaku Kogyo). After 20 min incubation at $37^{\circ} \mathrm{C}$, the remaining dsDNA segments were precipitated with cold $10 \%$ TCA and collected on a membrane filter (type HA; Millipore). The membranes were dried and the radioactivity was measured. DNA similarity values were calculated by dividing the counts per minute of the heterologous S1 nuclease-resistant DNA by the counts per minute of the homologous S1 nuclease-resistant DNA and multiplying by 100 . A correction was made for self-reassociation of labelled DNA using calf thymus DNA as control. The thermal stabilities of the DNA-DNA hybrids were estimated using the $\mathrm{S} 1$ nuclease procedure described by Johnson (1981). 
Table 2. Positions of the primers used for $P C R$ amplification and sequencing of the $16 S$ rDNA

\begin{tabular}{|lcll|}
\hline Primer & Position* & \multicolumn{1}{c|}{ Sequence } & \multicolumn{1}{c|}{ Reference } \\
\hline SSU 27 & $8-27$ & 5'-AGAGTTTGATCMTGGCTCAG-3' & Dorsch \& Stackebrandt (1992) \\
SSU 536 & $515-536$ & 5'-GTGCCAGCMGCCGCGGTAATAC-3' & Dufresne et al. (1996) \\
SSU 1175' & $1175-1195$ & 5'-GACGTCATTCCCCTCCTTCCTC-3' & Dufresne et al. (1996) \\
SSU 926 & $908-926$ & 5'-AAACTYAAAKGAATTGACGC-3' & Dufresne et al. $(1996)$ \\
SSU 1492' & $1492-1513$ & 5'-TACGGYTACCTTGTTACGACTT-3' & Dorsch \& Stackebrandt (1992) \\
\hline
\end{tabular}

* Relative to E. coli $16 \mathrm{~S}$ rDNA sequence (Brosius et al., 1978).

Table 3. Phenotypic differences among species of the genus Porphyromonas

1, P. gulae Loup $1^{\mathrm{T}}+66$ isolates; 2, P. gingivalis ATCC $33277^{\mathrm{T}}+12$ isolates; 3 , P. endodontalis ATCC $35406^{\mathrm{T}} ; 4, P$.

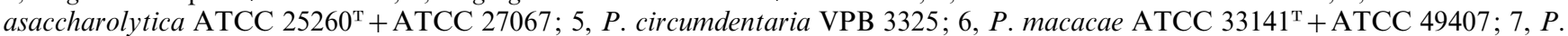
canoris NCTC $12835^{\mathrm{T}} ; 8, P$. gingivicanis ATCC $55562^{\mathrm{T}} ; 9, P$. crevioricanis ATCC $55563^{\mathrm{T}} ; 10$, , . cangingivalis $\mathrm{NCTC}^{12856^{\mathrm{T}}}$; 11 , P. cansulci NCTC $12858^{\mathrm{T}}$; 12 , P. catoniae ATCC $51270^{\mathrm{T}}$; 13 , P. levii ATCC $29147^{\mathrm{T}}$. Data from this study except where indicated. - , No activity; + , activity ( $97 \%$ positive); ND, not determined.

\begin{tabular}{|c|c|c|c|c|c|c|c|c|c|c|c|c|c|}
\hline Phenotypic feature & 1 & $2^{*}$ & 3 & 4 & 5 & 6 & $7 \dagger$ & $8 \ddagger$ & $9 \$$ & $10 \S$ & $11 \S$ & $12 \|$ & 13 \\
\hline UV fluorescence & - & - & + & + & + & $+(1 / 2)$ & + & ND & ND & - & + & ND & + \\
\hline Catalase & + & - & - & - & + & + & + & + & - & + & + & - & + \\
\hline Trypsin-like activity & + & + & - & - & - & + & - & - & - & - & - & - & - \\
\hline Haemagglutination & + & + & - & - & - & - & - & - & + & - & - & ND & - \\
\hline$\alpha$-Galactosidase & - & - & - & - & - & + & - & ND & ND & - & - & - & - \\
\hline$\beta$-Galactosidase & + & - & - & - & - & + & + & ND & ND & - & - & + & + \\
\hline$N$-Acetyl- $\beta$-glucosaminidase & + & + & - & - & - & + & + & - & - & - & - & + & + \\
\hline Indole production & + & + & + & + & + & + & + & + & + & + & + & - & - \\
\hline Arginine arylamidase & $+(64 / 66)$ & + & - & - & - & - & $\mathrm{ND}$ & ND & ND & ND & $\mathrm{ND}$ & ND & - \\
\hline$\alpha$-Fucosidase & - & - & - & + & - & - & - & - & - & - & - & + & - \\
\hline Glutamylglutamic acid arylamidase & + & - & - & - & + & - & ND & ND & ND & ND & ND & ND & + \\
\hline Propionic acid production & - & - & - & - & - & + & + & - & + & + & + & + & - \\
\hline Phenylacetic acid production & + & + & - & - & - & + & - & - & + & - & + & - & - \\
\hline
\end{tabular}

* Within the taxon P. gingivalis, two strains representing the Old World monkeys subgroup as hosts were also included.

$\dagger$ Data from Love et al. (1994).

† Data from Hirasawa \& Takada (1994).

$\S$ Data from Collins et al. (1994).

\| Data from Könönen et al. (1996).

Thermal melting points were used to determine the $\mathrm{G}+\mathrm{C}$ content of the DNA preparations (Johnson, 1981).

16S rDNA phylogenetic analysis. DNA was extracted from six $P$. gulae sp. nov. strains: Loup $1^{\mathrm{T}}$ (ATCC $51700^{\mathrm{T}}$ ), Chat 3.1, Chien 4.2, B 243, Ours 3.1 and Coyote 1.5.1, and from three $P$. gingivalis strains: ATCC $33277^{\mathrm{T}}$, Cerco 1.5 .2 and Manga 1.41 using the G NOME Kit (Bio101) according to the manufacturer's instructions. DNA purity was assessed by calculating the $A_{260} / A_{280}$ ratio measured on a spectrophotometer, and by agarose gel electrophoresis, comparing with Escherichia coli genomic DNA high-molecular-mass standards (Sigma-Aldrich).

Genes encoding 16S rRNA (rDNA) fragments corresponding to positions 8-1510 of E. coli (Brosius et al., 1978) were amplified in three tubes by using primer pairs SSU 27 and SSU 1492' (Table 2). The $40 \mu$ l PCR sequencing reaction mixtures contained $0.4 \mathrm{mM}$ (each) of the selected primers, $200 \mu \mathrm{M}$ of all four deoxyribonucleoside triphosphates (Pharmacia Biotech), $10 \mathrm{mM}$ Tris $/ \mathrm{HCl}$ pH 9.0, $50 \mathrm{mM} \mathrm{KCl}$, $0.1 \%$ Triton X-100, $2.5 \mathrm{mM} \mathrm{MgCl}_{2}, 0.5 \mathrm{U}$ Taq DNA polymerase (Promega) combined with the TaqStart anti- body (Clontech). The PCR mixtures were subjected to thermal cycling $\left(3 \mathrm{~min}\right.$ at $95^{\circ} \mathrm{C}$; and then 35 cycles of $60 \mathrm{~s}$ at $95^{\circ} \mathrm{C}, 60 \mathrm{~s}$ at $50^{\circ} \mathrm{C}$ and $1 \mathrm{~min}$ at $72{ }^{\circ} \mathrm{C}$; with a $7 \mathrm{~min}$ final extension at $72^{\circ} \mathrm{C}$ ) using a PTC-200 DNA Engine (MJ Research). The PCR product was resolved by electrophoresis through $1 \%(\mathrm{w} / \mathrm{v})$ agarose gels at $4 \mathrm{~V} \mathrm{~cm}^{-1}$ for $90 \mathrm{~min}$, and visualized with a white light box after staining with methylene blue (Flores, 1992) to avoid interference in the sequencing reaction. Bands were recovered from the gel by using the QIAquick Gel Extraction Kit (Qiagen). The amplicons were then used directly in the sequencing protocol. Both strands of amplified DNA were sequenced with the PRISM Ready Reaction DyeDeoxy Terminator Cycle Sequencing Kit using an Applied Biosystems 377 sequencer (PE Applied Biosystems). The sequence was amplified in overlapping fragments with the primers described in Table 2. The reactions were performed by using the same amplification primers and $100 \mathrm{ng}$ per reaction of the nucleic acid product. To exclude the possibility of sequencing errors attributable to misincorporations by the Taq DNA polymerase, each strand of the amplicon was sequenced from two different PCR reactions. 


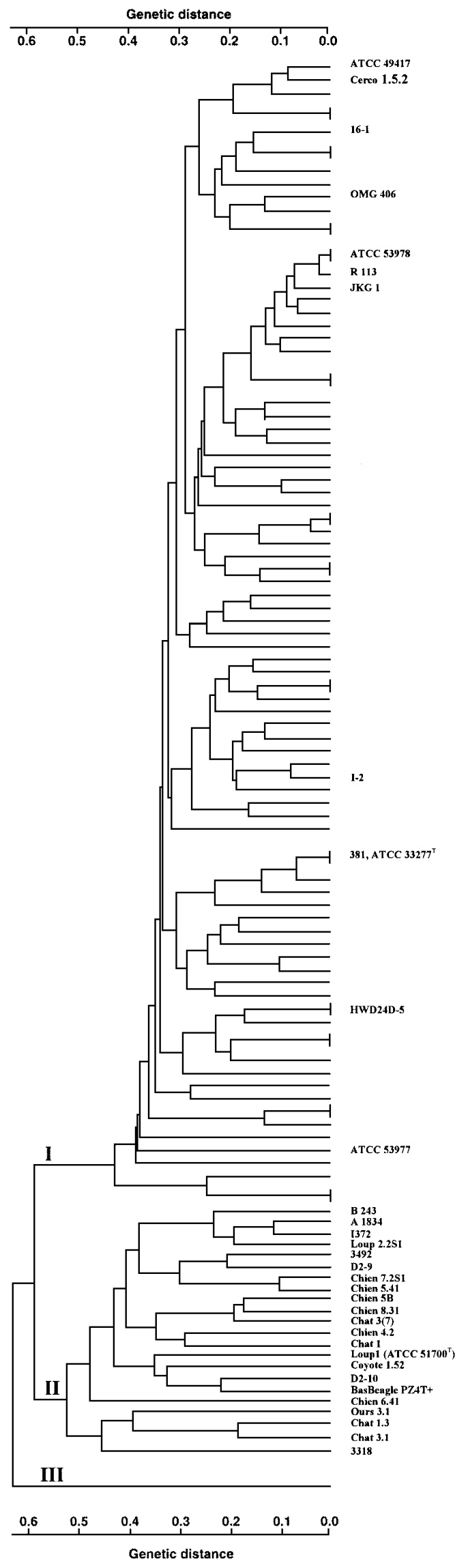

The $16 \mathrm{~S}$ rRNA sequences from the six $P$. gulae sp. nov. (former $P$. gingivalis animal biotype) strains, i.e. Loup $1^{\mathrm{T}}$ (ATCC $51700^{\mathrm{T}}$ ), Chat 1, Ours 3.1, B 243, Chien 4.2 and Coyote 1.5.1, were aligned with those from five $P$. gingivalis (human biotype), nine other Porphyromonas, five phylogenetically related species of Prevotella, Bacteroides and Flavobacterium genera, and two Bacillus species as outgroup. The resulting alignments of 1417 nucleotides with ambiguous regions removed (positions 1-109, 230-240, 481502, 589, 647-675, 833-887, 1027-1075, 1315 and 14631568) were subjected to phylogenetic analysis. Pairwise sequence identities were estimated and transformed in rate of substitution by the two-parameter method of Kimura (1980), and the phylogenetic tree was constructed by the neighbour-joining method (Saitou \& Nei, 1987) with PAUP version $4.0 \mathrm{~b} 4$ (Swafford, 2000). A bootstrap analysis with 500 replicates was conducted to confer a confidence level in the tree topology.

Nucleotide sequence accession numbers. The $16 \mathrm{~S}$ rDNA sequences obtained in this study have been deposited in the GenBank nucleotide sequence database under the following accession numbers: $P$. gulae sp. nov. Loup $1^{\mathrm{T}}$ (ATCC 51700 ${ }^{\mathrm{T}}$ ), AF208290; Chat 3.1, AF285871; Ours 3.1, AF285872; B 243, AF285874; Chien 4.2, AF285873; Coyote 1.5.1, AF287986; P. gingivalis ATCC $33277^{\mathrm{T}}$, AF285870; $P$. gingivalis Cerco 1.5.2, AF287987; P. gingivalis Manga 1.41, AF285869. The reference sequences used in the phylogenetic analysis were as follows: Bacteroides fragilis ATCC $25285^{\mathrm{T}}$, X83935; Bacteroides vulgatus ATCC 8482 ${ }^{\mathrm{T}}$, M58762; Bacillus coagulans IAM 12463, D16267; Bacillus subtilis NCDO 1769, X60646; Flavobacterium uliginosum ATCC $14397^{\mathrm{T}}$, M62749; P. asaccharolytica ATCC $25260^{\mathrm{T}}$, L16490; $P$. cangingivalis UPB 4874, X76259; $P$. cansulci UPB 4875, X76260; P. catoniae ATCC $51270^{\mathrm{T}}$, X82823; P. circumdentaria NCTC $12469^{\mathrm{T}}$, L26102; P. endodontalis ATCC $35406^{\mathrm{T}}$, L16491; $P$. gingivalis (W83), TIGR genome project, not yet released; $P$. gingivalis DSM 20709, X73964; Porphyromonas macacae ATCC $33141^{\mathrm{T}}$, L16494; P. macacae NCTC 11632, L26103; Prevotella intermedia ATCC $25611^{\mathrm{T}}$, L16468; Prevotella nigrescens ATCC $33563^{\mathrm{T}}$, L16471.

\section{RESULTS}

\section{Isolation and growth of strain collection}

Table 1 shows the geographical and host diversity of the $P$. gingivalis animal biotype received strains and fresh isolates included in this study. Only those from monkeys could be associated with an alteration of the tooth-supporting tissues. The others were usually isolated from healthy subgingival sites, or from sites with a minor presence of calculus. Brown- to blackpigmented colonies were obtained from subgingival plaques sampled from 17 animals, of which 7 gave a primary culture with more than one type of blackpigmented colony. After presumptive identification, a total of 86 isolates was classified Porphyromonas or Prevotella (data not shown).

Fig. 1. Dendrogram constructed from RAPD data indicating relationships among 129 isolates of $P$. gingivalis. A distance matrix was calculated by using the Nei and Li coefficient. The tree was generated from the distance matrix by UPGMA. (reprinted with permission from Ménard \& Mouton, 1995). 
Table 4. Levels of DNA-DNA relatedness (\%; data from Kato et al., 1997) and sequence similarity of 16S rRNAs among strains of $P$. gingivalis, $P$. gulae sp. nov. and related species

\begin{tabular}{|c|c|c|c|c|c|c|}
\hline \multirow[t]{2}{*}{ Source of unlabelled DNA } & \multicolumn{2}{|c|}{$\begin{array}{l}\text { P. gingivalis ATCC } 33277^{\mathrm{T}} \\
\text { (human biotype) }\end{array}$} & \multicolumn{2}{|c|}{$\begin{array}{l}\text { P. gingivalis Loup } 1^{\mathrm{T}} \\
\quad \text { (animal biotype) } \\
(P . \text { gulae } \text { sp. nov.) }\end{array}$} & \multicolumn{2}{|c|}{$\begin{array}{c}\text { P. gingivalis Chat } 3.1 \\
\text { (animal biotype) } \\
\text { (P. gulae sp. nov.) }\end{array}$} \\
\hline & DNA-DNA & 16S rDNA & DNA-DNA & 16S rDNA & DNA-DNA & 16S rDNA \\
\hline \multicolumn{7}{|l|}{$\begin{array}{l}P . \text { gingivalis } \\
\text { human biotype }\end{array}$} \\
\hline ATCC $33277^{\mathrm{T}}$ & $(100)^{*}$ & 100 & 58 & $98 \cdot 1$ & 62 & $98 \cdot 1$ \\
\hline W83 & - & $99 \cdot 4$ & - & 97.7 & - & 97.7 \\
\hline DSM 20209 & - & $99 \cdot 6$ & - & $98 \cdot 0$ & - & $98 \cdot 0$ \\
\hline Cerco & - & $99 \cdot 7$ & - & $98 \cdot 1$ & - & $98 \cdot 1$ \\
\hline Manga & - & $99 \cdot 7$ & - & $98 \cdot 1$ & - & $98 \cdot 1$ \\
\hline ATCC 53977 & 78 & - & 54 & - & 55 & - \\
\hline ATCC 49417 & 85 & - & 62 & - & 60 & - \\
\hline 381 & 85 & - & 54 & - & 68 & - \\
\hline OMG 406 & 91 & - & 63 & - & 58 & - \\
\hline $16-1$ & 84 & - & 54 & - & 61 & - \\
\hline HW24D5 & 75 & - & 63 & - & 63 & - \\
\hline $\mathrm{I}-2$ & 83 & - & 68 & - & 60 & - \\
\hline R113 & 84 & - & 55 & - & 60 & - \\
\hline JKG-1 & 82 & - & 60 & - & 55 & - \\
\hline \multicolumn{7}{|l|}{$\begin{array}{l}P . \text { gingivalis } \\
\text { animal biotype } \\
(P . \text { gulae sp. nov.) }\end{array}$} \\
\hline Loup $1^{\mathrm{T}}$ & 65 & $98 \cdot 1$ & (100) & 100 & 100 & $98 \cdot 8$ \\
\hline Chat 3.1 & 58 & $98 \cdot 1$ & 83 & $98 \cdot 8$ & (100) & 100 \\
\hline Chien 4.2 & 63 & $98 \cdot 1$ & 90 & $99 \cdot 9$ & 96 & 98.8 \\
\hline B 243 & 60 & $97 \cdot 9$ & 96 & $99 \cdot 4$ & 90 & $98 \cdot 5$ \\
\hline Ours 3.1 & 53 & $98 \cdot 0$ & 90 & $98 \cdot 8$ & 85 & $99 \cdot 9$ \\
\hline Chat 1.1 & 60 & - & 85 & - & 80 & - \\
\hline Coyote 1.5.1 & - & $97 \cdot 9$ & - & $99 \cdot 2$ & - & $98 \cdot 6$ \\
\hline \multicolumn{7}{|l|}{ P. cansulci } \\
\hline VPB 4875 & - & $89 \cdot 5$ & - & $89 \cdot 6$ & - & $89 \cdot 6$ \\
\hline \multicolumn{7}{|l|}{ P. catoniae } \\
\hline ATCC $51270^{\mathrm{T}}$ & - & $89 \cdot 6$ & - & $89 \cdot 7$ & - & $89 \cdot 7$ \\
\hline \multicolumn{7}{|l|}{ P. asaccharolytica } \\
\hline ATCC $25260^{\mathrm{T}}$ & 10 & - & 5 & - & 12 & - \\
\hline \multicolumn{7}{|l|}{ P. endodontalis } \\
\hline ATCC $35406^{\mathrm{T}}$ & 19 & - & 13 & - & 15 & - \\
\hline \multicolumn{7}{|l|}{ P. macacae } \\
\hline VPB 3313 & 18 & - & 8 & - & 13 & - \\
\hline ATCC $33141^{\mathrm{T}}$ & 11 & - & 3 & - & 10 & - \\
\hline \multicolumn{7}{|l|}{ P. levii } \\
\hline ATCC $29147^{\mathrm{T}}$ & 15 & - & 10 & - & 16 & - \\
\hline
\end{tabular}

*Value normalized to $100 \%$.

\section{Physiological and biochemical characteristics}

The use of new substrate analogues has definitely helped our presumptive identification of fresh isolates. According to some published work, the 4-methylumbelliferone derivatives could be a good alternative, especially for their sensitivity and accuracy (Moncla et al., 1991). Furthermore, this method has been specifically defined for black-pigmented organisms.

The typing scheme was employed and delimited a distinct group of 52 strains of animal origin. These strains were phenotypically similar to $P$. gingivalis but still remained unique (Table 3 ). The distinguishing 
criteria, also shared with the 15 strains received from other laboratories, were a positive catalase reaction, $\beta$ galactosidase activity ( $\beta$-GAL) and glutamylglutamic acid arylamidase activity (Fournier \& Mouton, 1993). All strains and fresh isolates haemagglutinated sheep erythrocytes, produced phenylacetic acid (PA) as a metabolic end product, possessed a trypsin-like activity and an $N$-acetyl- $\beta$-D-glucosaminidase activity $(\beta$-NAG) as did $P$. gingivalis human biotype. No fluorescence of the pigmented colonies under UV light was observed (Table 3). Strains from wolves and dog strains from Japan (D2-9, D2-10) also expressed a $\beta$ galactosidase-6-phosphate enzyme. Additionally, the coyote isolates all showed a pyroglutamic acid arylamidase activity (data not shown).

$P$. canoris, the newly named bacterial species associated with developing periodontitis in dogs, remained distinct from the above, in that it failed to haemagglutinate or to produce PA and showed no trypsin-like activity. $\beta$-GAL and $\beta$-NAG were detected, and an orange emission from colonies was seen under UV light. Haemagglutination, production of PA and trypsin-like activity were negative for $P$. gingivicanis. P. crevioricanis, which produced PA and haemagglutinated erythrocytes, showed no catalase or trypsin-like activity. $P$. cangingivalis was unique in its inability to produce measurable $\beta$-GAL, $\beta$-NAG, PA or haemagglutination activity. $P$. cansulci was distinguished by fluorescent colonies on blood agar, and by its lack of trypsin-like or haemagglutinating activities. Although $\beta$-GAL and $\beta$-NAG activities were present in $P$. catoniae, this species was quite distinct due to its lack of pigmentation and absence of catalase or trypsin-like activity, and failure to produce indole or PA (Table 3).

The colonies of $P$. macacae were rather brownpigmented, cells did not haemagglutinate, they showed $\alpha$-galactosidase activity and propionic acid appeared to be the major volatile metabolic end product. The discriminating criteria for $P$. circumdentaria were a positive UV fluorescence, no trypsin-like nor haemagglutinating activities, a negative enzymic detection for trypsin-like, $\beta$-GAL and $\beta$-NAG activities, and the absence of PA production.

\section{Summary of RAPD observations (Ménard \& Mouton, 1995)}

Four arbitrary primers were used to analyse the extent and nature of polymorphism in the $P$. gingivalis taxon. A first dendrogram obtained by hierarchical clustering of a data matrix of 66 discrete characters (major amplicons) revealed that 129 out of the 130 study isolates clustered in two major phylogenetic groups in which a total of 101 clonal types could be recognized (Fig. 1). A third group consisted of a single strain that was not used in the present study. Group I included all 98 human isolates, four of non-human primate (Old World monkeys) origin and one from dog (Chien N9). Group II consisted exclusively of animal strains,
Table 5. Thermal stability upon reassociation with labelled DNA from $P$. gingivalis ATCC 33277

Modified from Kato et al. (1997).

\begin{tabular}{|lc|}
\hline DNA from strain & $\Delta \boldsymbol{T}_{\mathrm{m}}(\mathrm{e})$ value $\left({ }^{\circ} \mathrm{C}\right)$ \\
\hline $\boldsymbol{P}$. gingivalis human biotype & \\
ATCC 33277 & 0 \\
HW24D5 & $0 \cdot 5$ \\
ATCC 53977 & $0 \cdot 5$ \\
$\boldsymbol{P}$. gingivalis & \\
animal biotype & \\
$(\boldsymbol{P}$. gulae sp. nov.) & \\
Loup 1 & $5 \cdot 5$ \\
Chien 4.2 & $5 \cdot 5$ \\
\hline
\end{tabular}

including three non-human primate (New World monkey) isolates. Group III consisted of one animal strain isolated from a sheep with broken mouth disease (not included in the present study). The average genetic distances between groups were as follows: between groups I and II, 0.58; between groups I and III, 0.59; and between groups II and III, 0.78. The average genetic distance between isolates of group II $(0 \cdot 43)$ was higher than for group I $(0.32)$, the latter reflecting the great diversity of hosts in group II. Interestingly, isolates from a carrier species, i.e. dog, cat, etc., were never seen to group in a given subcluster. This presumably reflected the higher diversity of the animal population studied (nine mammalian species). From our data, the existence of two phyla can be inferred.

\section{Summary of DNA homology data (Kato et al., 1997)}

By comparison with the reference strain ATCC $33277^{\mathrm{T}}$, the animal isolates shared a DNA homology of only 53-65\% (Table 4). In turn, using strain Loup $1^{\mathrm{T}}$ as a reference, the relatedness within the animal biotype was more than $83 \%$, but decreased to around $60 \%$ by comparison to strains from human origin. Another strain of the animal biotype, Chat 3.1, gave similar observations. These values are too low for $P$. gingivalis human biotype and $P$. gingivalis animal biotype ( $P$. gulae sp. nov.) to be considered members of the same species. The intraspecies level of $P$. gulae sp. nov. DNA-DNA relatedness is $80 \%$ and higher. The similarity is lowered if the hybridization is done with $P$. gingivalis $(\sim 60 \%), P$. endodontalis $(14 \%)$, Porphyromonas levii $(13 \%)$, P. asaccharolytica $(10 \%)$ and P. macacae (9\%) (Table 4) (Kato et al., 1997). In addition, thermal stability experiments of hybrids were carried out using strains from the human biotype with the lowest percentage hybridization with the reference ATCC $33277^{\mathrm{T}}$, i.e. ATCC 53977 and HW24D5; and amongst the animal biotype strains, those with the highest values, i.e. Loup $1^{\mathrm{T}}$ and Chien 4.2 (Table 5). The hybrids of strains HW24D5/ATCC $33277^{\mathrm{T}}$ and 


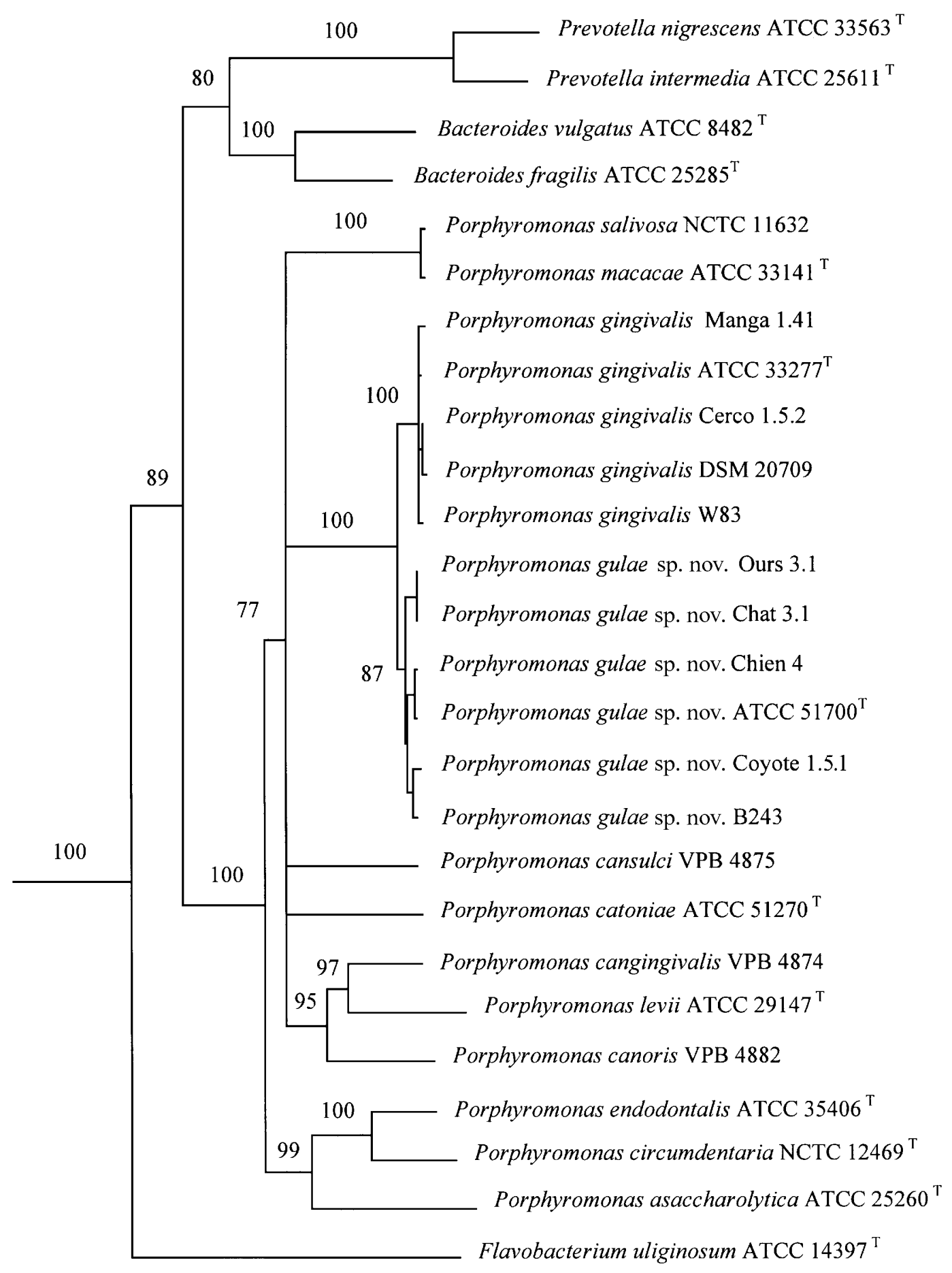

\section{- 0.01 changes}

Fig. 2. $16 \mathrm{~S}$ rDNA sequence phylogenetic tree showing the position of $P$. gulae sp. nov. within the Porphyromonas genus and related taxa. The branching pattern was generated by the neighbour-joining method and the bootstrap values, shown at the nodes, were calculated from 500 replicates. The scale bar indicates 1 inferred nucleotide substitution per 100 nucleotides.

ATCC 53977/ATCC $33277^{\mathrm{T}}$, which showed below $80 \%$ DNA homology values, had a $\Delta T_{\mathrm{m}}(\mathrm{e})$ of $0 \cdot 5^{\circ} \mathrm{C}$. In contrast, the hybrids Loup $1^{\mathrm{T}} / \mathrm{ATCC} 33277^{\mathrm{T}}$ and strains Chien 4.2/ATCC $33277^{\mathrm{T}}$, which gave relatively the highest percentage of reassociation values, had a $\Delta T_{\mathrm{m}}(\mathrm{e})$ higher than $5^{\circ} \mathrm{C}$ (Table 5). 


\section{Phylogenetic analysis by 16S rRNA comparison}

For each target strain, the sequencing results for the two PCR reactions were identical. In addition, the sequences of both strands were $100 \%$ complementary, thus confirming the high accuracy of the data. The $\mathrm{G}+\mathrm{C}$ content of the $16 \mathrm{~S}$ rDNA was $53.8 \mathrm{~mol} \%$ for proposed $P$. gulae sp. nov. type strain i.e. Loup $1^{\mathrm{T}}$, and the strain shared $98.1 \%$ identity with $P$. gingivalis of human origin and only $89.5 \%$ with the other nearest Porphyromonas species, i.e. P. cansulci (Table 4, Fig. 2). P. canoris, associated with developing periodontitis in dogs, remained distinct from $P$. gulae. The identity between the $P$. gingivalis strains of human origin was $99 \cdot 7 \%$.

\section{DISCUSSION}

The results presented in this paper reveal a paradox in bacterial systematics that is not restricted to the $P$. gingivalis taxon (Fox et al., 1992). We compared a set of strains of animal origin, closely resembling $P$. gingivalis found in humans, which can be distinguished phenotypically and exhibit sufficient genotypic differences from the latter (Loos et al., 1993; Ménard \& Mouton, 1993, 1995) to be correctly assigned to a different genospecies on the basis of accepted criteria. Data on DNA-DNA similarity (Table 4) (Kato et al., 1997) confirmed the heterogeneity found between the two biotypes of $P$. gingivalis and delineated $P$. gulae sp. nov. according to standard criteria (Wayne et al., 1987). However, when we compared sequences in genes encoding $16 \mathrm{~S}$ rRNA to clarify the phylogenetic position of the new species in the genus Porphyromonas, the difference between $P$. gulae sp. nov. and $P$. gingivalis was found to be sufficient to define a new genospecies but appeared tenuous.

The recognition of these two distinct phyla in monkey strains suggests the intriguing possibility that the most recent ancestors of human strains of $P$. gingivalis are closely related to the Old World monkey isolates or are those themselves. This recent divergence of the ancestral phylum may explain a less efficient resolution by the $16 \mathrm{~S}$ rDNA sequence analysis. This possibility needs to be investigated for a larger sample of strains from a variety of many non-human primate species indigenous to different parts of the world.

What is the range of $P$. gulae sp. nov.? Using the WEETAB System for biochemical identification, Hudspeth et al. (1997) found conflicting results between $P$. gingivalis ATCC $33277^{\mathrm{T}}$ and clinical strains isolated from infected dog and cat bites in humans. P. gingivalis ATCC $33277^{\mathrm{T}}$ was catalase and $\beta$-GAL negative, clinical strains were all catalase-positive and 7 out of $10(70 \%)$ were $\beta$-GAL positive. These two biochemical activities suggest that the clinical isolates are likely to be authentic $P$. gulae sp. nov. strains. In contrast, Citron et al. (1996) found weak $\beta$-GAL activity in $P$. gingivalis ATCC $33277^{\mathrm{T}}$ and clinical strains isolated from infected $\operatorname{dog}$ and cat bites in humans, while $P$. gingivalis ATCC $33277^{\mathrm{T}}$ demonstrated no $\beta$-GAL activity in current enzymic profiling (Durmaz et al., 1995). From published data it would appear that the bas beagle isolates known as 'canine Bacteroides' (former classification) (Shah \& Collins, 1988; Syed, 1980) and those studied by Yamasaki et al. (1990), as well as the cat strains that Love et al. (1990) introduced as $P$. gingivalis subsp. felis, most likely belong to the species $P$. gulae.

Allaker et al. (1997a, b) detected $P$. gingivalis in the supragingival dental plaque of $68 \%$ of healthy dogs. In contrast, the recently described $P$. canoris, Porphyromonas salivosa, $P$. cangingivalis, $P$. cansulci and $P$. crevioricanis were isolated in less than $9 \%$ of dogs. Moreover, $P$. gingivicanis was not isolated from any of the animals sampled (Allaker et al., 1997a, b). All $P$. gingivalis isolated from supragingival dental plaque of dogs in our laboratory, and not included in the present study, have been re-identified with our extended typing scheme. They all shared the biochemical characteristics and genetic markers of $P$. gulae (data not shown). Since the identification of $P$. gingivalis in the studies of Allaker et al. $(1997 \mathrm{a}, \mathrm{b})$ was based on a shorter set of phenotypic tests, we can infer that these strains truly belong to the new species $P$. gulae.

Wild animals were a good source of $P$. gulae sp. nov. In the present study, most of them had spent a significant portion of their life in captivity. The coyote was an exception because it was recovered during winter from a trap set by poachers, brought to the Québec City Zoo and sampled the same day. The primary culture of its dental plaque gave black-pigmented colonies, most of them being $P$. gulae sp. nov. The diet is known to play a selective role on the dental flora. In this case, protein shortage during winter may have altered the composition of the normal flora, thus allowing bacterial overgrowth of $P$. gulae sp. nov. in the oral cavity of this mammal.

According to previous results (Fournier \& Mouton, 1993; Kato et al., 1997; Ménard \& Mouton, 1993, 1995; Parent et al., 1986) and the present study, it can be inferred that $P$. gingivalis cannot be found in dogs and other animals, with the exception of non-human primates from the Old World (Ménard \& Mouton, 1995). Moreover, it would appear that $P$. gulae sp. nov. is the most prominent species of the genus Porphyromonas to be found in the oral cavity of mammals.

\section{Description of Porphyromonas gulae sp. nov.}

Porphyromonas gulae (gu'lae. L. n. gula [animal] mouth; N.L. gen. n. gulae from the animal mouth, referring to its isolation from subgingival plaque of various animal hosts).

Cells are obligately anaerobic, non-spore-forming, non-motile, Gram-negative rods or coccoid forms. From Todd-Hewitt broth cultures or blood agar plates, the following cellular morphologies can be 
observed. The size of cells ranges from 0.5 to $0.9 \mu \mathrm{m}$ by 1.0 to $4.0 \mu \mathrm{m}$. Cells are arranged singly, in short chains or in groups; some filaments up to $10 \mu \mathrm{m}$ are occasionally seen. After $48 \mathrm{~h}$ growth on solid media, colonies are $0.5-3.5 \mathrm{~mm}$ in diameter, with a circular form, an entire margin, a convex elevation and a mucoid aspect. A brown to black pigment is produced on ageing of the cultures. Moreover, colonies do not fluoresce under UV light $(\lambda=366 \mathrm{~nm})$. Vitamin $\mathrm{K}_{1}$ and haemin are required for growth. Mannose and raffinose are not fermented.

The major metabolic end products in Todd-Hewitt broth are butyric acid, isovaleric acid, succinic acid and phenylacetic acid. Strains are all catalase-positive and indole is produced. Alkaline phosphatase, trypsinlike and $\beta$-NAG activities are strong. $\beta$-GAL and glutamylglutamic acid arylamidase activities are present. Urea is not used and nitrate is not reduced. Cells significantly haemagglutinate sheep erythrocytes and are resistant to kanamycin $\left(50 \mu \mathrm{g} \mathrm{ml}^{-1}\right)$.

All isolates came from subgingival plaque samples of various mammals, including cat, dog, coyote, wolf, bear and non-human primate from the New World i.e. squirrel monkey and black spider monkey. The sites were mainly healthy, or with a minor presence of calculus. The $\mathrm{G}+\mathrm{C}$ content of the DNA is $51 \mathrm{~mol} \%$. The average level of intraspecies DNA-DNA homology is $80 \%$ and higher. The DNA-DNA relatedness with related species is $P$. gingivalis $(\sim 60 \%), P$. endodontalis $(14 \%)$, P. levii $(13 \%), P$. asaccharolytica $(10 \%)$ and $P$. macacae $(9 \%)$. The type strain of $P$. gulae sp. nov. is Loup $1^{\mathrm{T}}\left(=\right.$ ATCC $51700^{\mathrm{T}}=\mathrm{NCTC}$ $\left.13180^{\mathrm{T}}\right)$.

\section{ACKNOWLEDGEMENTS}

We thank F. Chandad and M. Boissinot for helpful suggestions, Michel G. Bergeron for providing automatic sequencing facilities and D. Mayrand for the GLC and some field strains. We are also grateful to the following researchers who sent valuable strains for this study: B. G. Loos, D. N. Love, W. P. McArthur, K. Okuda and S. A. Syed. We thank R. Patenaude (from the Québec City Zoo), L. Paradis and A. Bernal for technical assistance and D. Ní Edhin for editorial assistance. A part of this work was supported by grant MA8761 from the Medical Research Council of Canada.

\section{REFERENCES}

Allaker, R. P., de Rosayro, R., Young, K. A. \& Hardie, J. M. (1997a). Prevalence of Porphyromonas and Prevotella species in the dental plaque of dogs. Vet Rec 140, 147-148.

Allaker, R. P., Young, K. A., Langlois, T., de Rosayro, R. \& Hardie, J. M. (1997b). Dental plaque flora of the dog with reference to fastidious and anaerobic bacteria associated with bites. $J$ Vet Dent 14, 127-130.

Brosius, J., Palmer, M. L., Kennedy, P. J. \& Noller, H. F. (1978). Complete nucleotide sequence of a $16 \mathrm{~S}$ ribosomal RNA gene from Escherichia coli. Proc Natl Acad Sci USA 75, 4801-4805.

Citron, D. M., Hunt Gerardo, S., Claros, M. C., Abrahamian, F., Talan, D. \& Goldstein, E. J. C. (1996). Frequency of isolation of
Porphyromonas species from infected dog and cat bite wounds in humans and their characterization by biochemical tests and arbitrarily primed-polymerase chain reaction fingerprinting. Clin Infect Dis 23 (Suppl. 1), S78-S82.

Collins, M. D., Love, D. N., Karjalainen, J. \& 8 other authors (1994). Phylogenetic analysis of members of the genus Porphyromonas and description of Porphyromonas cangingivalis sp. nov., and Porphyromonas cansulci sp. nov. Int J Syst Bacteriol 44, 674-679.

Dorsch, M. \& Stackebrandt, E. (1992). Some modifications in the procedure of the direct sequencing of PCR amplified 16S rDNA. J Microbiol Methods 16, 271-279.

Dufresne, S., Bousquet, J., Boissinot, M. \& Guay, R. (1996). Sulfobacillus disulfidooxidans sp. nov., a new acidophilic, disulfide-oxidizing, Gram-positive, spore-forming bacterium. Int J Syst Bacteriol 46, 1056-1064.

Durmaz, B., Jousimies-Somer, H. R. \& Finegold, S. M. (1995). Enzymatic profiles of Prevotella, Porphyromonas, and Bacteroides species obtained with the API ZYM system and Rosco diagnostic tablets. Clin Infect Dis 20 (Suppl. 2), S192-S194.

Felsenstein, J. (1993). PHYLIP (Phylogeny Inference Package) version 3.5c. Department of Genetics, University of Washington.

Flores, N., Valle, F., Bolivar, F. \& Merino, E. (1992). Recovery of DNA from agarose gels stained with methylene blue. Biotechniques 13, 203-205.

Fournier, D. \& Mouton, C. (1993). Phenotypic characterization of human and animal biotypes within the species Porphyromonas gingivalis. Res Microbiol 144, 435-444.

Fox, G. E., Wisotzkey, J. D. \& Jurtshuk, P. J. (1992). How close is close: 16S rRNA sequence identity may not be sufficient to guarantee species identity. Int J Syst Bacteriol 42, 166-170.

Hirasawa, M. \& Takada, K. (1994). Porphyromonas gingivicanis sp. nov. and Porphyromonas crevioricanis sp. nov. isolated from beagles. Int J Syst Bacteriol 44, 637-640.

Holdeman, L. V., Cato, E. P. \& Moore, W. E. C. (1977). Anaerobe Laboratory Manual. Blacksburg: Virginia Polytechnic Institute and State University.

Hudspeth, M. K., Hunt Gerardo, S., Citron, D. M. \& Golstein, E. J. C. (1997). Growth characteristics and a novel method for identification (the WEE-TAB System) of Porphyromonas species isolated from infected $\operatorname{dog}$ and cat bite wounds in humans. J Clin Microbiol 35, 2450-2453.

Johnson, J. (1981). Genetic characterization. In Manual of Methods for General Microbiology, pp. 450-472. Edited by P. Gerhardt. Washington, DC: American Society for Microbiology.

Jousimies-Somer, H. (1995). Update on the taxonomy and the clinical and laboratory characteristics of pigmented anaerobic Gram-negative rods. Clin Infect Dis 20 (Suppl. 2), S187-S191.

Jousimies-Somer, H. (1997). Recently described clinically important anaerobic bacteria: taxonomic aspects and update. Clin Infect Dis 25 (Suppl. 2), S78-S87.

Kato, T., Okuda, K., Takazoe, I., Fujisawa, T. \& Mitsuaoka, T. (1987). Antigenic heterogeneity of non-pigmented Bacteroides species isolated from the human cavity. J Dent Res 66, 996-999.

Kato, T., Hirai, K., Okuda, D., Fournier, D., Ménard, C. \& Mouton, C. (1997). Animals are not reservoir for the human periodontal pathogen. Dentistry Jpn 33, 27-30. 
Kimura, M. (1980). A simple method for estimating evolutionary rates of base substitutions through comparative studies of nucleotide sequences. J Mol Evol 16, 111-120.

Könönen, E., Väisänen, M.-L., Finegold, S. M., Heine, R. \& Jousimies-Somer, H. (1996). Cellular fatty acid analysis and enzyme profiles of Porphyromonas catoniae-a frequent colonizer of the oral cavity in children. Anaerobe 2, 329-335.

Laliberté, M. \& Mayrand, D. (1983). Characterization of blackpigmented Bacteroides strains isolated from animals. $J$ Appl Bacteriol 55, 247-252.

Legendre, P. \& Vaudor, A. (1991). The R package: multidimensional analysis, spatial analysis. Département des Sciences Biologiques, Université de Montréal.

Loos, B. G., Dyer, D. W., Whittam, T. S. \& Selander, R. K. (1993). Genetic structure of populations of Porphyromonas gingivalis associated with periodontitis and other oral infections. Infect Immun 61, 204-212.

Love, D. N., Vekselstein, R. \& Collings, S. (1990). The obligate and facultatively anaerobic bacterial flora of the normal feline gingival margin. Vet Microbiol 22, 267-275.

Love, D., Bailey, G., Collings, S. \& Briscoe, D. (1992). Description of Porphyromonas circumdentaria sp. nov. and reassignment of Bacteroides salivosus (Love, Johnson, Jones, and Calverley 1987) as Porphyromonas (Shah and Collins 1988) salivosa comb. nov. Int $J$ Syst Bacteriol 42, 434-438.

Love, D. N., Karjalainen, J., Kanervo, A., Forsblom, B., Sarkiala, E., Bailey, G. D., Wigney, D. I. \& Jousimies-Somer, H. (1994). Porphyromonas canoris sp. nov., an asaccharolytic, blackpigmented species from the gingival sulcus of dogs. Int J Syst Bacteriol 44, 204-208.

Marmur, J. (1961). A procedure for the isolation of deoxyribonucleic acid from microorganisms. J Mol Biol 3, 208-218.

Ménard, C. \& Mouton, C. (1993). Randomly amplified polymorphic DNA analysis confirms the biotyping scheme of Porphyromonas gingivalis. Res Microbiol 144, 445-455.

Ménard, C. \& Mouton, C. (1995). Clonal diversity of the taxon Porphyromonas gingivalis assessed by random amplified polymorphic DNA fingerprinting. Infect Immun 63, 2522-2531.

Ménard, C., Brousseau, R. \& Mouton, C. (1992). Application of polymerase chain reaction with arbitrary primer (AP-PCR) to strain identification of Porphyromonas (Bacteroides) gingivalis. FEMS Microbiol Lett 95, 163-168.

Moncla, P., Braham, P., Rabe, L. \& Hillier, S. (1991). Rapid presumptive identification of black-pigmented Gram-negative anaerobic bacteria by using 4-methylumbelliferone derivatives. J Clin Microbiol 29, 1955-1958.
Moore, L. V. H. \& Moore, W. E. C. (1994). Oribaculum catoniae gen. nov., sp. nov.; Catonella morbi gen. nov., sp. nov.; Halella seregens gen. nov., sp. nov.; Johnsonella ignava gen. nov., sp. nov.; and Dialister pneumosintes gen. nov., comb. nom. rev., anaerobic Gram-negative bacilli from the human gingival crevice. Int J Syst Bacteriol 44, 187-192.

Nei, M. \& Li, W. H. (1979). Mathematical model for studying genetic variation in terms of restriction endonucleases. Proc Natl Acad Sci US A 76, 5269-5273.

Parent, R., Mouton, C., Lamonde, L. \& Bouchard, D. (1986). Human and animal serotypes of Bacteroides gingivalis defined by crossed immunoelectrophoresis. Infect Immun 51, 909-918.

Rigby, P., Dieckmann, M., Rhodes, C. \& Berg, P. (1977). Labeling deoxyribonucleic acid to high specific activity in vitro by nick translation with DNA polymerase I. J Mol Biol 113, 237-251.

Saitou, N. \& Nei, M. (1987). The neighbor-joining method: a new method for reconstructing phylogenetic trees. Mol Biol Evol 4, 406-425.

Shah, H. N. \& Collins, M. D. (1988). Proposal for reclassification of Bacteroides asaccharolyticus, Bacteroides gingivalis, and Bacteroides endodontalis in a new genus, Porphyromonas. Int $J$ Syst Bacteriol 38, 128-131.

Sneath, P. H. A. \& Sokal, R. R. (1973). Numerical Taxonomy - the Principles and Practice of Numerical Classification. San Francisco: Freeman.

Swafford, D. (2000). Phylogenetic analysis using parsimony (*and other methods), version 4.0b4. Sunderland, MA: Sinauer Associates.

Syed, S. A. (1980). Characteristics of Bacteroides asaccharolyticus from dental plaques of beagle dogs. J Clin Microbiol 11, 522-526.

Wayne, L. G., Brenner, D. J., Colwell, R. R. \& 9 other authors (1987). International Committee on Systematic Bacteriology. Report of the ad hoc committee on reconciliation of approaches to bacterial systematics. Int J Syst Bacteriol 37, 463-464.

Willems, A. \& Collins, M. D. (1995). Reclassification of Oribaculum catoniae (Moore and Moore 1994) as Porphyromonas catoniae comb. nov. and emendation of the genus Porphyromonas. Int J Syst Bacteriol 45, 578-581.

Williams, J. G. K., Kubelik, A. R., Livak, K. J., Rafalski, J. A. \& Tingey, S. V. (1990). DNA polymorphisms amplified by arbitrary primers are useful as genetic markers. Nucleic Acids Res 18, 6531-6535.

Yamasaki, T., Nagata, A., Kiyoshige, T., Sato, M. \& Nakamura, R. (1990). Black-pigmented, asaccharolytic Bacteroides species resembling Porphyromonas gingivalis (Bacteroides gingivalis) from beagle dogs. Oral Microbiol Immunol 5, 332-335. 